\title{
Energy Saving System by Means of Electrical and Geo- Referential Identification of Load
}

\author{
Carlos Reynoso, Erick Cruz, Pedro Palomo, Mario Chauca
}

FIEE-UNAC Universidad Nacional del Callao, Juan Pablo II 306, Bellavista 07011 Callao, Perú

\begin{abstract}
In this project you have the control of the passage of the current in each outlet, for example, in a house where each outlet will be registered with a certain continuous electrical power for appliances, computers, among others. Every electrical device that has been registered and is connected to any outlet will work, if any other device that has not been registered is connected, it will not work in any socket. In addition, once any power outlet is connected, the system will detect where it is connected and we will know the place where it was connected. With this project, we will have a lower cost of electricity and economic savings. Keywords: Arduino, Sensor, Electric Current, Saving, Hall.
\end{abstract}

\section{Introduction}

The human being as such through his reason we use natural resources, we transform them and we use them for some necessary good, such is the case of the electricity that today is the main source of energy that makes all apparatus, machine work either for domestic use as well as for the industrial.

Unlike commodities or other private services, electricity has certain technical and economic characteristics that condition the organizational structure of the industry that provides it. [1]

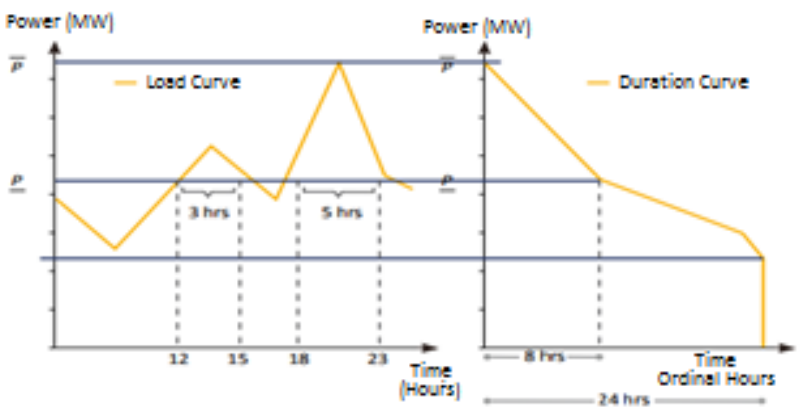

Fig. 1. Represents the maximum demand of the day, while representing the average demand of historical power. [2]

The electrical demand is characterized by registering a variable behavior during the day as shown in Fig. 1. The scheme that shows this particularity is called curve or load diagram, which allows the identification of periods of high or low demand called peak hours and off-peak hours, respectively. [3]

The public electricity service in the city of Lima is commercialized and distributed between two companies that divide the market according to geographical criteria, without competing among them: Luz del Sur and Enel DP. Luz del Sur, is the concessionaire of the public electricity service for the districts located in the southern part of the city up to the province of Cañete. Enel DP as shown in Table 1, for its part, has the concession of the distribution and commercialization of electricity in the northern area of Metropolitan Lima, in the Constitutional Province of Callao and the provinces of Huaura, Huaral, Barranca and Oyón. [4]

Table 1. Customers served by Enel DP in terms of electricity distribution service. [5]

\begin{tabular}{|c|c|c|c|c|}
\hline \multirow{2}{*}{$\begin{array}{c}\text { Type of } \\
\text { Clients }\end{array}$} & \multicolumn{2}{|c|}{ Number of Clients } & \multicolumn{2}{c|}{ Billed Energy (GWh) } \\
\cline { 2 - 5 } & Mar.16 & Mar.17 & Mar.16 & Mar. 17 \\
\hline Residential & $94.73 \%$ & $94.81 \%$ & $35.37 \%$ & $41.64 \%$ \\
\hline Commercial & $3.15 \%$ & $3.08 \%$ & $20.05 \%$ & $14.78 \%$ \\
\hline Industrial & $0.09 \%$ & $0.10 \%$ & $15.51 \%$ & $23.32 \%$ \\
\hline Others & $2.03 \%$ & $2.00 \%$ & $18.55 \%$ & $14.89 \%$ \\
\hline Tolls & $0.00 \%$ & $0.01 \%$ & $10.52 \%$ & $5.37 \%$ \\
\hline Total & $100.00 \%$ & $100.00 \%$ & $100.00 \%$ & $100.00 \%$ \\
\hline
\end{tabular}

As shown in Fig. 2, due to the increase in consumption and the rate it is necessary to create some kind of energy saving mechanism, for this we will make a saving system that allows to cut the flow of current when the person is not in said place.

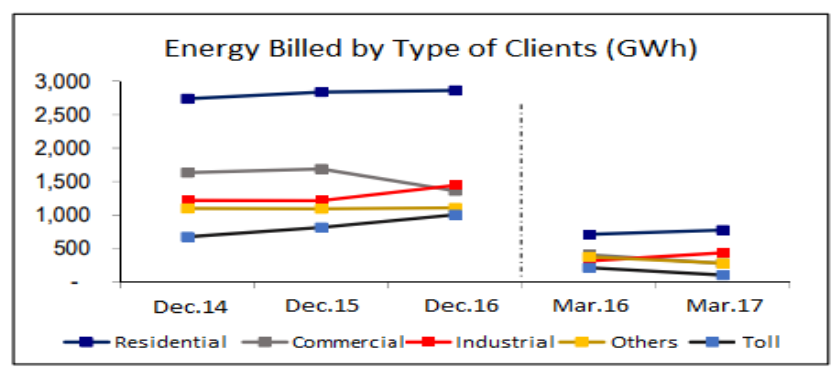

Fig. 2. Consumption of electric energy generated by different sectors [6]. 


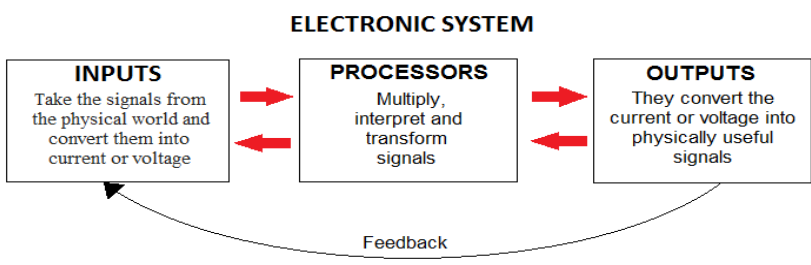

Fig. 3. Scheme of an electronic system [7].

The microcontrollers have played an important role in the development of multiple tasks as shown in Fig. 4 the analysis of various controllers, this being a fundamental tool for scientific and technological development, knowing about these minicomputers is very important, since They find in our work, our home, in the same computers, in aerospace projects, among others. Where by with this an electronic system is obtained as shown in Fig. 3.

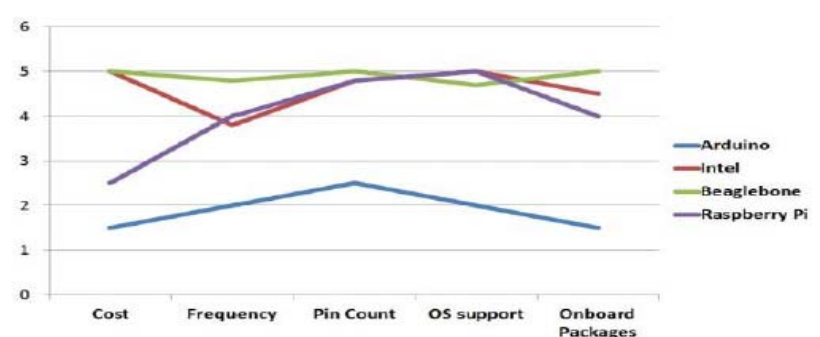

Fig. 4. Analysis of the various controllers [8].

There are studies that indicate that household income is strongly related to energy consumption, but this is a trend, not a rule. Income is not the only factor that determines the modality of energy consumption (Alemu, et al., 2009).

With the technological advance and the generation of new and cheaper sources for the generation of energy, it is possible to imagine that the homes that are in the lower levels of the stairs can make the leap to more efficient energies [9]

It is necessary to carry out evaluations projected in the medium and long term of the national energy demand, the results will be used for the elaboration of an integrated and concerted energy planning that will allow having timely signals to define general energy policies, goals and deadlines to ensure the supply of energy. Energy and social welfare. [10]

The Hall effect, This situation is characterized by the potential difference that appears between the edges as shown in Fig. 5 called Hall voltage, if I is the current intensity, $\mathrm{B}$ the magnetic field, $\mathrm{n}$ the density of carriers, $\mathrm{q}$ its loading and the width of the sheet.[11]

$$
V_{\text {Hat }}=\frac{I B}{n q d}
$$

The potential can be written as:

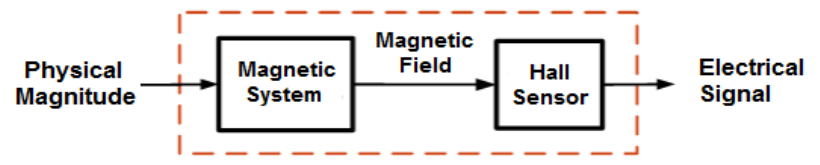

Fig. 5. Internal diagram of the Hall Effect [12].
This stage is powered by a digital output, interposing an optocoupler to galvanically isolate both circuits. We also add a flyback diode, which are included in the relay module as shown in Fig. 6. [13]

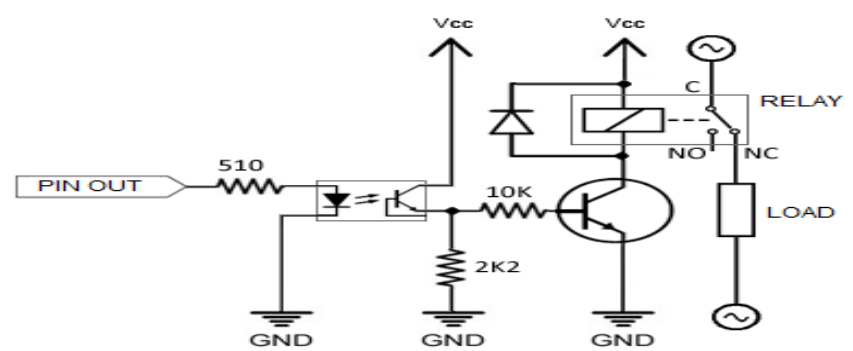

Fig. 6. One channel relay module circuit [14].

Experimental engineering, environmental control, automobiles, appliances, computers, are tasks that would be indispensable without the application of sensors, such as the ACS712 current sensor.

ACS712 current sensor, shown in Fig. 7, is a Hall effect current sensor, which provides an economical and accurate solution for measuring current in $\mathrm{AC}$ or DC, whether in industrial or commercial environments. [1516]

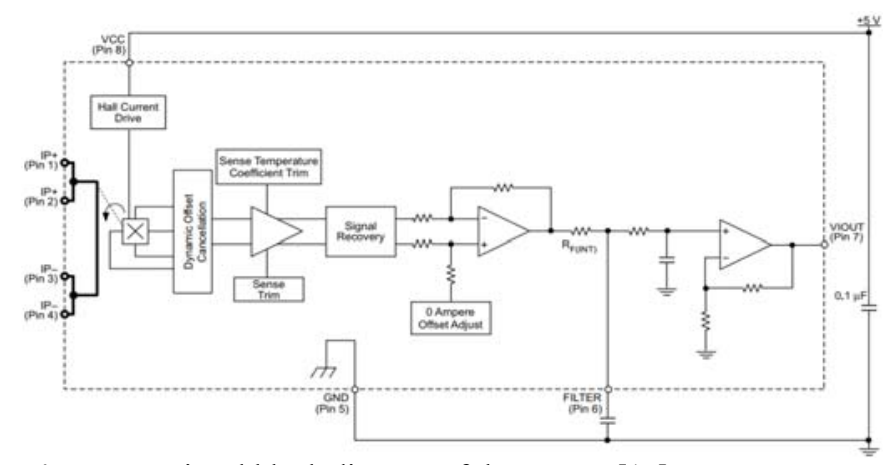

Fig. 7. Functional block diagram of the sensor. [17].

Table 2. The range of current, model and sensitivity of the integrated.

\begin{tabular}{|l|l|l|}
\hline \multicolumn{1}{|c|}{ Model } & \multicolumn{1}{c|}{ Range } & \multicolumn{1}{c|}{ Sensitivity } \\
\hline ACS712ELCTR-05B-T & -5 a 5A & $185 \mathrm{mV} / \mathrm{A}$ \\
\hline ACS712ELCTR-20A-T & -20 a $20 \mathrm{~A}$ & -20 a $20 \mathrm{~A}$ \\
\hline ACS712ELCTR-30A-T & -30 a 30 A & $66 \mathrm{mV} / \mathrm{A}$ \\
\hline
\end{tabular}

Table 2 shows the types of ACS72 sensors. The sensor gives us a value of 2.5 volts for a current of $0 \mathrm{~A}$ and thereafter increases proportionally according to the sensitivity, having a linear relationship between the voltage output of the sensor and the current. This relationship is a straight line in a graph Voltage vs Current where the slope is the sensitivity and the intersection in the $\mathrm{Y}$ axis is 2.5 volts. [18]

The equation of the line would be the following:

$$
V=m I+2.5
$$

Where: $\mathrm{m}$ : It is the slope and is equivalent to the Sensitivity.

$$
I=\frac{V-2.5}{\text { Sensibilidad }}
$$


Clearing we will have the equation to find the current from the sensor reading. [19-22] In the following way we calculate the energy consumption: Power $\mathrm{x}$ Time $=$ Consumption (energy consumed). This energy consumed in a given time is measured in Kwh. This is the unit of measurement that utilities use to collect what their customers consume per month.

$$
\begin{aligned}
& \mathrm{K}=\text { kilo }=1000 \\
& \mathrm{~W}=\text { watts }=\text { power unit } \\
& \mathrm{H}=\text { hora }=\text { unit of time }
\end{aligned}
$$

$1 \mathrm{Kwh}$ consumed for 10 hours per day, which is the equivalent of keeping 10 100-watt lamps on for 10 continuous hours, yields an energy consumption of 10 Kwh / day, which in turn remains constant during the 30 days one month we will have an energy consumption of

\begin{tabular}{|c|c|c|c|c|c|}
\hline \multicolumn{2}{|l|}{ Local } & \multicolumn{4}{|c|}{ de Ceniral de la Superintendencia Nacional de Educacion Superior Universilaria } \\
\hline \multicolumn{2}{|c|}{ Tipo de tarifa : BT3 } & \multicolumn{3}{|c|}{ Consumo de energia } & \multirow{2}{*}{ Importe Total S/ (recibo) } \\
\hline Mes & NPReclbo & Hora Punta (hw.h) & Fuera Punta (kw.h) & Total (kw.h) & \\
\hline Enero & 196254822 & $9.255,00$ & $42.105,00$ & $51.360,00$ & $27.387,60$ \\
\hline Febréro & 197399134 & $9.900,00$ & $46.600,00$ & $56.500,00$ & $21.540,60$ \\
\hline Marzo & 196428993 & 9660,00 & $52.670,00$ & $62.330,00$ & $26.526,20$ \\
\hline Abril & 199519144 & $8.790,00$ & $48.060,00$ & $56.850,00$ & $24.388,10$ \\
\hline Mayo & 200611694 & $8.330 ; 00$ & $40,730,00$ & $49.060,00$ & $21.076,67$ \\
\hline Junio & 201705892 & $8.080,00$ & $37.010,00$ & $45,090,00$ & $19.704,90$ \\
\hline Julio & 202802235 & $7.540,00$ & $33.970,00$ & $41,510,00$ & $19.483,00$ \\
\hline Agosio & 203901109 & $7.970,00$ & $35.170,00$ & $43.140,00$ & $20.136,50$ \\
\hline Septiembre & 205001962 & $8.350,00$ & $36.570,00$ & $44,920,00$ & $19.018,80$ \\
\hline Oclubre & 206105728 & $8.600,00$ & $35.660,00$ & $44.260,00$ & $20.157,90$ \\
\hline Noviembre & 207212744 & 8660,00 & $37.720,00$ & $46,380,00$ & $19.498,60$ \\
\hline Dictembre & 208322828 & $8.260,00$ & $38.790,00$ & $47,050,00$ & $21.152,40$ \\
\hline Total & & $103.395,00$ & $485,055,00$ & $450.760,00$ & $260.071,27$ \\
\hline
\end{tabular}
$300 \mathrm{Kwh} / \mathrm{month}$. We use this calculation of Electric Power in the SUNEDU in 2017 as shown in Fig. 8.

Fig. 8. Electric Power Consumption at the SUNEDU 2017 headquarters. [23].

\section{Process}

a) Measurement of the peak-to-peak voltage by software, samples are taken (100, 500 and 1000 for different cases) of the signal presented by the DC/AC current sensor, this is a signal composed of a direct current component with voltage $\mathrm{Vcc} / 2$ (2.5 volts approximately) plus an AC component directly proportional to the current to be measured (from the ACS712 datasheet it is known that the sensitivity is $0.185[\mathrm{~V} / \mathrm{A}]$ ), the voltage (only the AC component) is shown delivers the sensor compared to the voltage of the power source. In the samples, there is a high probability of obtaining the maximum and minimum voltage added to the inherent noise of the sensor operation, then the peak-to-peak voltage is obtained by means of equation (4).

$$
\begin{aligned}
& V_{p p}=V_{\max }-V_{\min } \\
& V_{p p}=2 \sqrt{2} V_{r m s}
\end{aligned}
$$

From equation (4) you have to

$$
V_{r m s}=\frac{1}{2 \sqrt{2}} V_{p p}
$$

Including the typical sensitivity of the ACS712 sensor version 5 amperes:

$$
\text { sensibilidad }=0.185[\mathrm{~V} / \mathrm{A}]
$$

In the reverse way:

$$
\frac{1}{\text { sensibilidad }}=5.4054[\mathrm{~A} / \mathrm{V}]
$$

And you get the rms current flowing through the sensor:

$$
I_{r m s}=\frac{5.4054}{2 \sqrt{2}} V_{p p}=1.9111 * V_{p p}
$$

On the other hand, we know that $\mathrm{S}$ (apparent power) is obtained through:

$$
\mathrm{S}=\mathrm{Vrms} \times \mathrm{Irms} \quad \text { [VA] }
$$

The Arduino code of the implementation is shown, the result is displayed in a serial terminal, the Irms current that flows through the sensor is seen in addition to the apparent power (presented as consumption).

b) Measurement of the average AC current by sampling the voltage of the $\mathrm{AC}$ current that the sensor delivers with samples $n=[100,500,1000]$, finally Assuming an rms voltage of $1147 \mathrm{~V}$ the apparent power is calculated.

$$
V_{p p}=\pi \mathrm{V}_{\mathrm{avr}}
$$

From (5) and (11) we obtain:

$$
\pi V_{a v r}=2 \sqrt{2} V_{r m s}
$$

From this equation you get:

$$
V_{r m s}=\frac{\pi}{2 \sqrt{2}} V_{a v r}=1.1107 * V_{a v r}
$$

If we also suppose a power factor close to the unit (if we think that the circuit will be applied in household consumption devices) it can be inferred from (13) that:

$$
I_{r m s}=\frac{\pi}{2 \sqrt{2}} I_{\text {avr }}=1.1107 * I_{\text {avr }}
$$

To measure the instantaneous current the following expression is used, since we have an ADC with resolution of 10 bits, reference voltage of 5 volts and sensitivity of $66 \mathrm{mV}$ :

$$
\begin{gathered}
I_{\text {inst }}=\frac{V_{\text {ref }}}{2^{n}-1} * \frac{1}{\text { sensibitidad }}\left(A D C_{\text {muestra }}-512\right) \\
=\frac{5.5 .4054}{1023}\left(A D C_{\text {muestra }}-512\right) \\
=0.0264\left(A D C_{\text {muestra }}-512\right) .
\end{gathered}
$$

The difference is that the contactor handles high powers and the relay manages low powers. There are manufacturers that are within the manufacturing range can make changes or contactors with ranges of powers that are reduced between them, even between different manufacturers, different ranges in what is called relay and contactor. But in essence the difference remains the same as the same. For this reason, it was decided to use the relay for the lower cost as shown in Fig. 9.

\section{1 Design}




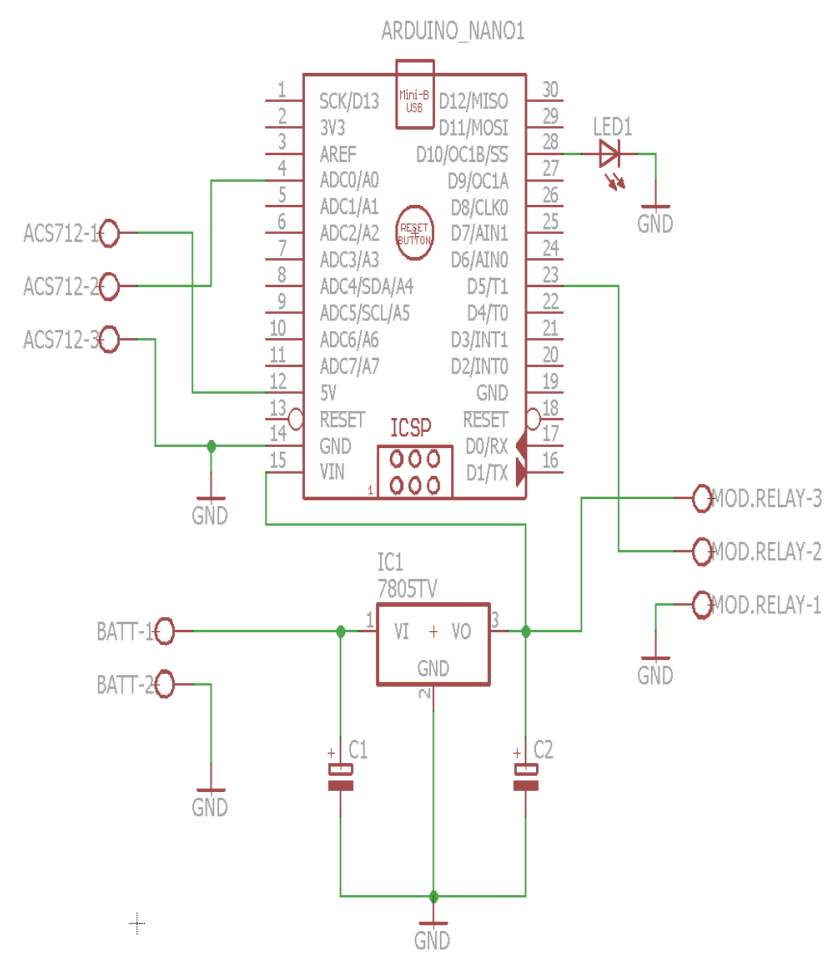

Fig. 9. Circuit Design.

2.2 Block Diagram as shown in Fig. 10.

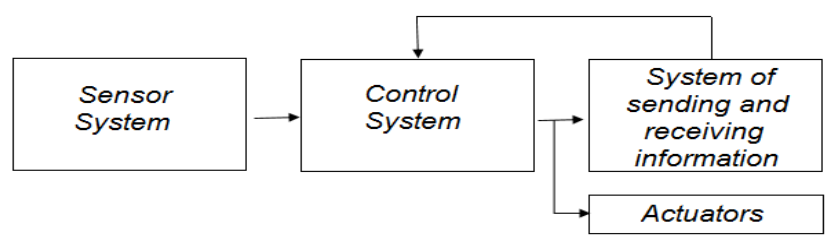

Fig. 10. Block diagram energy saving system. [15].

\subsection{Flow Diagram as shown in Fig.11.}

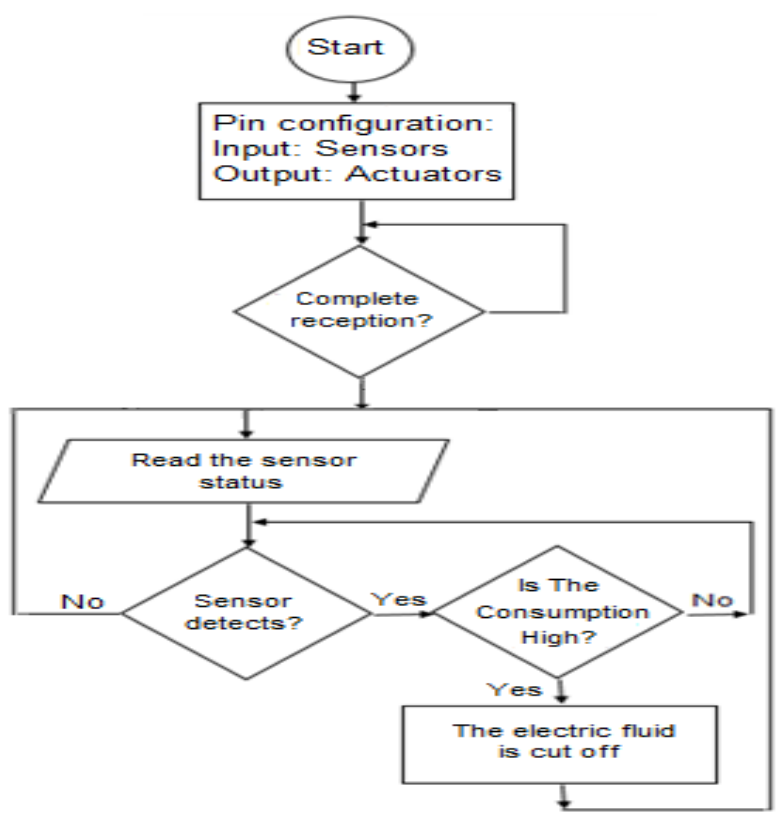

Fig. 11. Automatic ignition system flow diagram.

\section{Results}

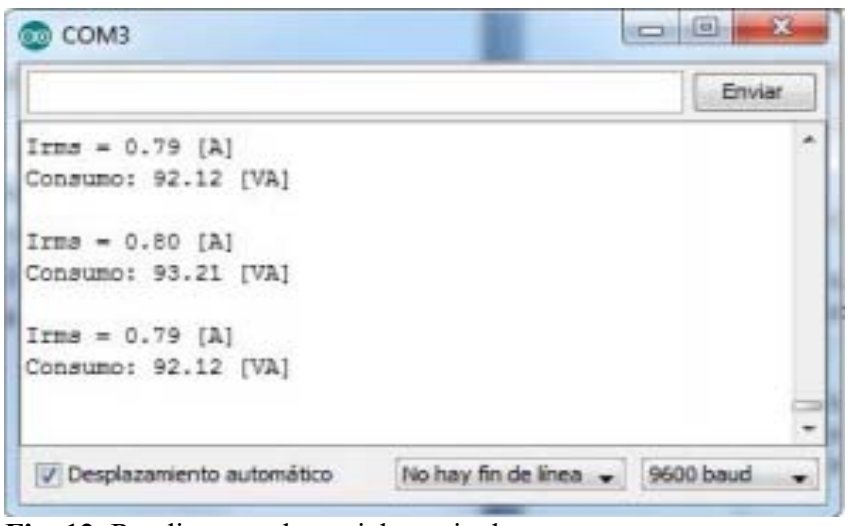

Fig. 12. Readings on the serial terminal.

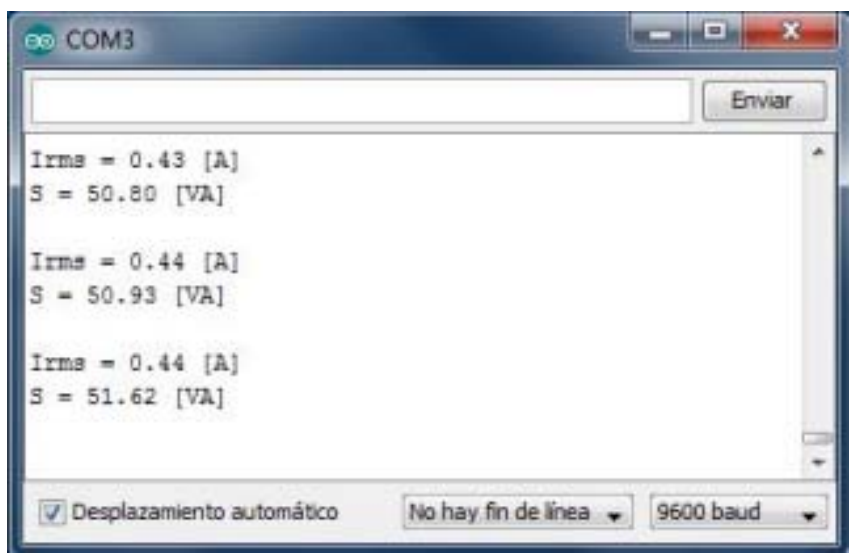

Fig. 13. More accurate reading of the current sensor.

Table 3. Sample of the consumption of the possible household appliances at home.

\begin{tabular}{|c|c|c|}
\hline Artifact & Consumption(W) & Consumption Total (W) \\
\hline Therma & 1500 & \multirow{11}{*}{6500} \\
\hline Computer & 300 & \\
\hline Blender & 300 & \\
\hline Microwave & 1100 & \\
\hline Refriferator & 350 & \\
\hline Griddle & 1000 & \\
\hline Washing Machine & 500 & \\
\hline Dryer & 1200 & \\
\hline Stereo & 80 & \\
\hline TV $20^{\prime \prime}$ & 120 & \\
\hline Fan & 50 & \\
\hline
\end{tabular}

The result of consumption as shown in Fig.14. 


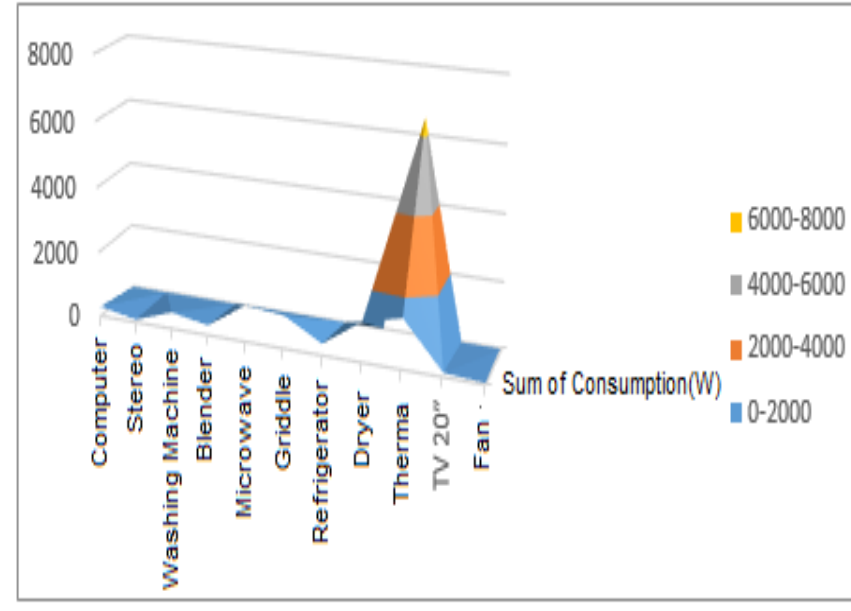

Fig. 14. Result of consumption in Table 3.

Table 4. - Authorized and unauthorized loads.

\begin{tabular}{|l|c|c|c|}
\hline \multicolumn{1}{|c|}{ Artifact } & Authorization & Consumption(W) & Consumption Total (W) \\
\hline Therma & $X$ & 1500 & \\
\hline Computer & $\checkmark$ & 300 & \\
\hline Blender & $\checkmark$ & 300 & \\
\hline Microwave & $X$ & 1100 & \multirow{3}{*}{1350} \\
\hline Refififerator & $X$ & 350 & \\
\hline Griddle & $X$ & 1000 & \\
\hline Washing Machine & $\checkmark$ & 500 \\
\hline Dryer & $X$ & 1200 \\
\hline Stereo & $\checkmark$ & 80 & \\
\hline TV 20" & $\checkmark$ & 120 & \\
\hline Fan & $\checkmark$ & 50 & \\
\hline
\end{tabular}

Where: - authorized device - unauthorized device

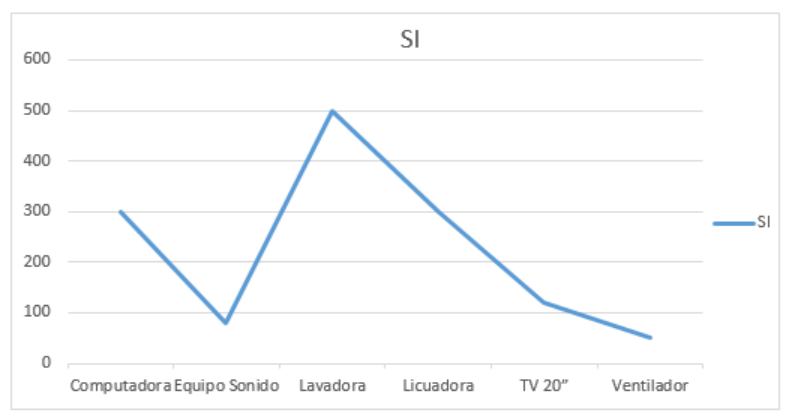

Fig. 15. Graph only of authorized charges.

\section{Conclusions}

- There is an error of $9 \%$ in the reading value, attributable to the electrical noise of the sensor as shown in Fig. 12.

- There is no significant difference in the number of samples taken for the calculation of the peak-to-peak voltage and later the rms current. However, this approach does not ensure that in all cases the peak-to- peak value is obtained due to the randomness of sampling as shown in Table 3.

- The results are applicable only to resistive loads, capacitive or inductive loads could cause erroneous readings.

- In Fig. 13 we can notice that the value varies from 50.80 to 50.93 (Volts) in an error of approximately $3 \%$, it can be seen that this solution is closer to the expected values, this is therefore a significant improvement compared to the first approximation as shown in Fig. 12.

- It was observed that the sensor is affected by the presence of intense magnetic fields, taking care not to operate the sensor in places with magnetic contamination such as near electric motors or transformers.

- Only the authorized loads will work, when any plug that has been registered is connected, it would not have electric power as shown in Table 4 and Fig. 15.

\section{References}

1. LA INDUSTRIA DE LA ELECTRICIDAD EN EL PERU, 25 años de aportes al crecimiento económico del Perú-OSINERGMIN ISBN: 978-612-47350-0-4

2. LA INDUSTRIA DE LA ELECTRICIDAD EN EL PERU, 25 años de aportes al crecimiento Económico del Perú-OSINERGMIN ISBN: 978612-47350-0-4.

3. INFORME DE CLASIFICACIÓN DE RIESGO ENEL DISTRIBUCIÓNPERUS.A.A.Sesión de Comité No $37 / 2017$

4. Arduino. Curso Práctico de formación. Oscar Torrente Artero. Primera Edición. Alfaomega. Grupo editor, México, febrero 2013. ISBN 9876077076483.

5. LA ESCALERA ENERGÉTICA: MARCO TEÓRICO Y EVIDENCIAS PARA EL PERÚREPORTE ESPECIAL DE ANÁLISIS ECONÓMICO No 001-2017-GPAE/OS Febrero 2017. TABLA I

6. EL CONSUMO MINIMO DE ENERGIA ELECTRICA y su relación con la selección de beneficiarios del Vale de Descuento FISE Año 3$\mathrm{N}^{\circ} 4$ - Abril 2015- Proyecto FISE -Osinergmin.

7. PROYECCIÓN DEL CONSUMO DE ENERGÍA RESIDENCIAL EN EL PERÚ (2005-2030) Revista de la Facultad de Ingeniería. Industrial Vol. 12(2): pp 50-60 (2009) UNMSM ISSN: 1560-9146/ISSN: 1810-9993.

8. Web:http://saber.patagoniatec.com/sensor-decorriente-acs 712-5-20-30a-ptec-arduino-pic/.

9. Web:http://pdf1.alldatasheet.com/datasheetpdf/view /168326/ALLEGRO/ACS712.html

10. Domótica para ingenieros. J. Maestre. 1ra edición. Editorial Paraninfo, S.A. Madrid, España, 2015. ISBN: 978-84-9732-976.

11. Universidad Nacional de San Luis Facultad de Ciencias Físico Matemáticas y Naturales Ingeniería Electrónica con orientación en Sistemas Digitales Técnico Universitario en Microprocesadores 
Profesorado en Tecnología Electrónica- Sensores de efecto Hall, Figura 5

12. Smart (Home) Control. Werner Harke. 1ra edición. Editorial C.F.Müller, Alemania, 2010. ISBN: 97837-880-7801-0.

13. Sistemas eléctricos y de seguridad y confortabilidad. O. Barrera.J. Ros. 2da edición. Editorial Paraninfo, S. A. Madrid, España, 2016. ISBN 978-84-2833824-0.

14. Sensores y Acondic ionadores de señal. Pallas, Ramón. Editorial Marcombo, SA. Cuarta edición 2005. ISBN 8426713440.

15. Ciencia y tecnología e innovación para el desarrollo y lacohesión social. Bravo Murillo. Madrid-España. ISBN 9788476662403.

16. Web:"Arduino ile Neler Yapllabilmektedir?" http://arduinoturkiye.com/arduino-nedir-ve-nedegildir/ 2016.
17. Web:Anonymous 2013 Roboweb.net Web Sitesi; http://www.roboweb.net/blog/arduino-satinalimkilavuzu/ 2016.

18. Ingeniería de Control Moderno. K. Ogata, 5ta edición. Editorial Prentice Hall, Madrid, España, 2016.

19. Web: Anonim http://arduino.nedir.com Erişim Tarihi 19 Kasım 2016.

20. Daniel Pardo Collantes y Luis A. Bailón Vega. (2006). Fundamentos de Electrónica Digital. (1a ed.). España: Ediciones Universidad Salamanca.

21. Web:http://pdf1.alldatasheet.com/datasheetpdf/view /168326/ALLEGRO/ACS712.html.

22. Bartra, L. (2016). Distribución Eléctrica. Materiales de Clase, XIV Curso de Extensión Universitaria Osinergmin.

23. Web:https://intranet.sunedu.gob.pe/documentos/dire ctorios/192/energia-electrica-diciembre.pdf 